\title{
Asymmetric aziridination of $N$-tert-butanesulfinyl imines with phenyldiazomethane via sulfur ylides ${ }^{1}$
}

\author{
Zheng Xue, Veronica M. Dee, Louisa J. Hope-Weeks, Bruce R. Whittlesey, \\ and Michael F. Mayer* \\ Department of Chemistry and Biochemistry, Texas Tech University, Lubbock, \\ TX 79409-1061, USA \\ E-mail address:mf.mayer@ttu.edu
}

Dedicated to Professor Richard A. Bartsch on the occasion of his $70^{\text {th }}$ birthday

\begin{abstract}
Optically active aziridines were synthesized from the reaction of chiral nonracemic $N$-tertbutanesulfinyl imines with benzyl-stabilized sulfur ylides, wherein the latter were generated from a rhodium-catalyzed decomposition of phenyldiazomethane (PDM) in the presence of various sulfides. In most cases, the aziridines were formed and isolated in quantitative yield and the 2,3trans-aziridines were found to predominate over the 2,3-cis-aziridine isomers. The diastereoselectivity between the two trans-aziridines was found to vary significantly, depending upon the solvent and sulfide employed in the reaction.
\end{abstract}

Keywords: Aziridines, $N$-sulfinyl imines, phenyldiazomethane, sulfur ylides

\section{Introduction}

Aziridines are three-membered, nitrogen-containing heterocycles. The aziridine functionality has been found to occur in several biologically-potent natural products; furthermore, aziridines are versatile precursors to numerous other nitrogen-containing functional groups. ${ }^{2}$ Thus, many excellent methods have been developed to access aziridines in both racemic and optically active forms. ${ }^{3}$ Nevertheless, there remains much room for improvement in the methods to access optically-active functionalized aziridines.

Among the precursors used in asymmetric aziridine syntheses, imines have served as highly convenient starting materials due to their ease of synthesis (or in situ generation) and their relative reactivity. ${ }^{4}$ In one approach beginning with imines, an asymmetric Corey-Chaykovskytype reaction has been developed utilizing achiral sulfur ylides and readily available asymmetric 
$N$-sulfinyl imines. ${ }^{5-7}$ However, this approach generally requires use of strong base to generate the ylide and therefore suffers associated limitations.

In part to address this limitation, Aggarwal et al., developed an asymmetric aziridination under neutral conditions from reaction of achiral imines with chiral sulfur ylides, which were generated in situ from a transition metal-catalyzed decomposition of a diazo compound in the presence of catalytic quantities of a chiral sulfide. ${ }^{8}$ While the literature is replete with various examples of aziridine-forming reactions from diazo compounds and imines, we noticed a complete absence of examples of aziridine formation from the reaction of diazo compounds with readily available asymmetric $N$-sulfinyl imines. ${ }^{9}$ This seemed intriguing given that such imines have been extensively employed in recent years in a manifold of organic transformations, thus providing a wide range of synthetically important nitrogen-containing compounds with excellent enantiocontrol. In particular, two highly useful classes of asymmetric $N$-sulfinyl imines are the $N$ - $p$-toluenesulfinyl imines and the $N$-tert-butanesulfinyl imines. ${ }^{10}$

With regard to aziridine synthesis from chiral $N$-sulfinyl imines, there have indeed been several reports. Examples include reactions of optically pure $N$ - $p$-toluenesulfinyl imines with $\alpha$ bromoenolates, ${ }^{11} \alpha$-chloro- $N$-tert-butanesulfinyl imines with Grignard reagents, ${ }^{12}$ and $N$-tertbutanesulfinyl imines with various nucleophiles such as phosphonate anions, ${ }^{13}$ allenylzinc reagents, ${ }^{14}$ telluronium ylides, ${ }^{15}$ and sulfur ylides. ${ }^{5}$ However, to the best of our knowledge, asymmetric aziridine synthesis from the reaction of readily available chiral $N$-sulfinyl imines with diazo compounds has not been reported in the literature. Herein, we wish to disclose our results on the study of the aziridination of asymmetric $N$-tert-butanesulfinyl imines $\mathbf{1}$ with phenyldiazomethane (PDM, 2), which thus fills the gap in reported knowledge in this methodological area and may also serve as a complementary method to existing methods of asymmetric aziridine synthesis.

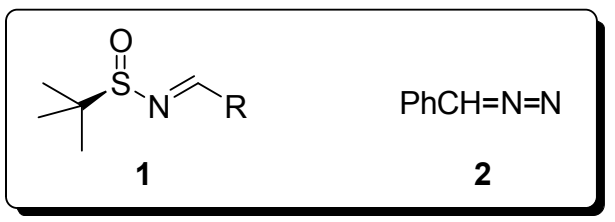

\section{Results and Discussion}

The synthesis of aziridines from Lewis acid-catalyzed reaction of imines and diazo compounds has been an ongoing subject of research in our laboratories. ${ }^{16}$ Accordingly, our initial efforts were focused on the reaction of asymmetric $N$-tert-butanesulfinyl imines with diazo compounds in the presence of catalytic amounts of Brønsted acids and Lewis acids. However no aziridine formation was observed under ambient conditions when $\mathrm{N}$-tert-butanesulfinyl imines bearing electron-deficient (e.g. 1a, 4- $\mathrm{NO}_{2}-\mathrm{C}_{6} \mathrm{H}_{4}$ ) or electron-rich (e.g. 1b, 4-MeO-C $\mathrm{C}_{4}$ ) aromatic substituents were employed in a reaction with ethyl diazoacetate (EDA), 
trimethylsilyldiazomethane (TMSD) or PDM 2. We thus turned our attention to the sulfur ylidemediated reaction that involves an in-situ conversion of the diazo compound into the more reactive sulfur ylide, under neutral conditions, in the presence of a transition metal catalyst and a sulfide.

Aziridine formation still failed to occur from the reactions of either EDA or TMSD with 1a in the presence of catalytic amounts of $\mathrm{Rh}_{2}(\mathrm{OAc})_{4}$ and tetrahydrothiophene (THT). However, we were pleased to observe that when PDM was reacted with 1a, in dichloromethane at room temperature in the presence of $1 \mathrm{~mol} \% \mathrm{Rh}_{2}(\mathrm{OAc})_{4}$ and $50 \mathrm{~mol} \% \mathrm{THT}$, the corresponding aziridines 3a were formed in quantitative yield (entry 1 in Table 1). Under otherwise identical conditions, lowering the reaction temperature was found to have little effect on the diastereoselectivity and it led to a lower conversion of the imine (entry 2 in Table 1). Although the stereoselectivities observed here were moderate as compared to the previously reported aziridination reactions via sulfur ylide addition to $N$-sulfinyl imines, under basic conditions, the complete and clean conversion of the imine to the aziridines represented the highest efficiency among these methods. Importantly, the presence of all four isomers of the aziridine products would allow for some mechanistic examination of the reaction selectivity. A screen of various solvents was performed and the results are summarized in Table 1.

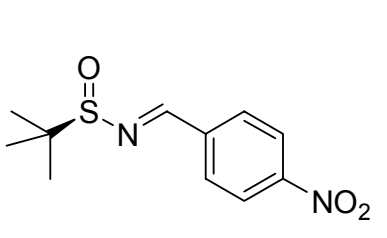

$1 \mathrm{a}$

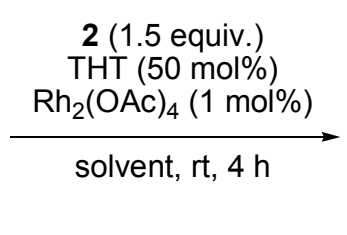

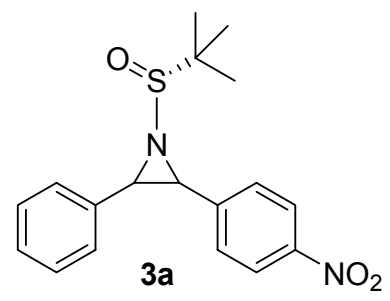

With all of the tested solvents, the trans-aziridines were selectively formed over the cisaziridines. The predominant formation of 2,3-trans-aziridine isomers is consistent with a known kinetically-controlled mechanism of benzyl-stabilized sulfur ylide-mediated aziridination of imines. $^{7 e, 17}$ The highest diastereomeric excess (d.e.) of the major trans isomer was found for the reaction run in toluene (entry 6 in Table 1). The major trans isomer was isolated in $57 \%$ yield and its structure was confirmed by single crystal X-ray crystallographic analysis as $\left(R_{\mathrm{S}}, 2 R, 3 R\right)-1$ (tert-butanesulfinyl)-2-(4-nitrophenyl)-3-phenylaziridine $\quad\left(\left(R_{\mathrm{S}}, 2 R, 3 R\right)-3 \mathbf{a}\right), \quad$ Figure $\quad 1 \mathrm{a} .{ }^{18}$ Conversely, when polar aprotic solvents were applied, the selectivity was found to be reversed such that the other trans isomer $\left(R_{\mathrm{S}}, 2 S, 3 S\right)$-3a was the major product, again as confirmed by single crystal X-ray crystallographic analysis, Figure $1 \mathrm{~b} .{ }^{18}$ For example, when the reaction was carried out in acetonitrile, $\left(R_{\mathrm{S}}, 2 S, 3 S\right)$-3a was obtained in $45 \%$ isolated yield (entry 8 in Table 1$)$. Unfortunately, the trans/cis ratio slightly dropped in acetonitrile compared with reactions performed in the other solvents. Interestingly, the trans/cis ratio was greatest (9:1) when DMSO was used (entry 9 in Table 1); however in this case the total aziridine yield was significantly decreased due to side reactions. 
Table 1. Solvent effect on the sulfur ylide-mediated reaction of imine 1a with PDM 2

\begin{tabular}{lllll}
\hline Entry & Solvent & ${\text { Trans }: \text { cis }^{\mathrm{a}}}$ & $\begin{array}{l}\text { D.e. trans- } \\
\left(R_{\mathrm{S}}, 2 R, 3 R\right)-\mathbf{3 a}^{\mathrm{a}}\end{array}$ & Yield $^{\mathrm{b}, \mathrm{c}}$ \\
\hline 1 & dichloromethane & $78: 22$ & $<5 \%$ & $99(39)$ \\
$2^{\mathrm{d}}$ & dichloromethane & $71: 29$ & $<5 \%$ & $\sim 40 \%$ conv. \\
3 & THF & $77: 23$ & $7 \%$ & $99(41)$ \\
4 & $1,4-$ dioxane & $80: 20$ & $23 \%$ & $\sim 89 \%$ conv. \\
5 & benzene & $79: 21$ & $34 \%$ & $99(53)$ \\
6 & toluene & $81: 19$ & $41 \%$ & $99(57)$ \\
7 & chlorobenzene & $80: 20$ & $26 \%$ & $99(50)$ \\
8 & acetonitrile & $66: 34$ & $(42 \%)^{\mathrm{e}}$ & $99(45)$ \\
9 & DMSO & $90: 10$ & $(36 \%)^{\mathrm{e}}$ & $64(40)$ \\
\hline
\end{tabular}

${ }^{a}$ Determined from the ${ }^{1} \mathrm{H}$ NMR spectrum of the crude product. ${ }^{\mathrm{b}}$ Combined isolated yield of cisand trans-aziridines. ${ }^{\mathrm{c}}$ In parentheses is the isolated yield of the major isomer. ${ }^{\mathrm{d}}$ Reaction was performed at $-78^{\circ} \mathrm{C} .{ }^{\mathrm{e}}\left(R_{\mathrm{S}}, 2 S, 3 S\right)-\mathbf{3 a}$ was the major product.

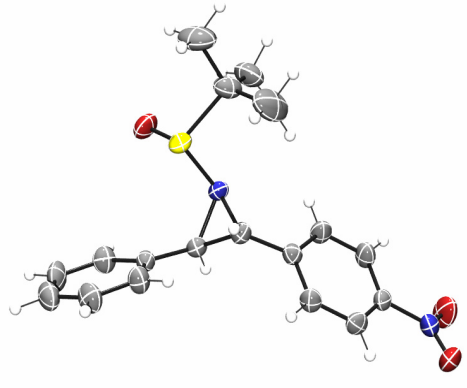

a

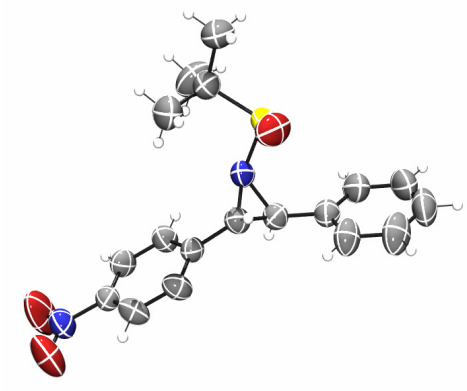

b

Figure 1. Single crystal X-ray structure of a) $\left(R_{\mathrm{S}}, 2 R, 3 R\right)-N$-(tert-butanesulfinyl)-2-(4nitrophenyl)-3-phenylaziridine $\left(\left(R_{\mathrm{S}}, 2 R, 3 R\right)-\mathbf{3 a}\right)$ and b) $\left(R_{\mathrm{S}}, 2 S, 3 S\right)-N$-(tert-butanesulfinyl)-2-(4nitrophenyl)-3-phenylaziridine $\left(\left(R_{\mathrm{S}}, 2 S, 3 S\right)-3 \mathbf{a}\right){ }^{18}$

In the ${ }^{1} \mathrm{H}$ NMR and ${ }^{13} \mathrm{C}$ NMR spectra of $\left(R_{\mathrm{S}}, 2 R, 3 R\right)-\mathbf{3 a}$, sharp well-resolved signals were observed and the ${ }^{3} J$ coupling constant of the two aziridine ring protons was found to be $3.9 \mathrm{~Hz}$, from which the 2,3-trans configuration was initially and properly assigned (see the Supplementary Material). In contrast, the ${ }^{1} \mathrm{H}$ NMR and ${ }^{13} \mathrm{C}$ NMR spectra of $\left(R_{\mathrm{S}}, 2 S, 3 S\right)-3 \mathbf{a}$ showed significantly broadened signals. This suggested that, in solution at room temperature, $\left(R_{\mathrm{S}}, 2 S, 3 S\right)$-3a may exist as two invertomers that undergo intermediate exchange on the NMR time scale, whereas $\left(R_{\mathrm{S}}, 2 R, 3 R\right)$-3a may exist either as a single invertomer or as two invertomers 
that are in fast exchange on the NMR time scale. For these enantiomerically pure aziridines, the dynamics were specifically proposed to be due to conformational equilibria between the two $\mathrm{N}$ invertomers, wherein the sulfinyl substituent on the aziridine nitrogen switches positions with respect to the plane of the aziridine ring. ${ }^{14 \mathrm{c}}$ Many studies regarding aziridine invertomers have been previously reported wherein the two invertomers could be distinguished by low temperature NMR studies and, on occasion, even physically separated from each other. ${ }^{19}$ In this case, both the ${ }^{1} \mathrm{H}$ NMR and ${ }^{13} \mathrm{C}$ NMR spectra of $\left(R_{\mathrm{S}}, 2 S, 3 S\right)$-3a obtained at $-20{ }^{\circ} \mathrm{C}$ sharpened and revealed two sets of signals with a ca. 1.5:1 integration ratio (see the Supplementary Material), indicating that the two invertomers are in slow exchange on the NMR time scale at this temperature, such that signals due to both invertomers could be resolved and observed.

As discussed above, the choice of solvent was found to have a significant effect on the diastereoselectivity of the trans-aziridines, although, for the most part, no major difference regarding the total aziridine yield was observed upon solvent change. With the two complementary solvents, toluene and acetonitrile, which gave rise to the two trans-aziridines with the highest but opposite diastereoselectivities, different sulfides were tested for each solvent, with 1a as the substrate, under the standard reaction conditions.

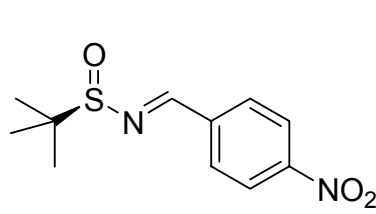

$1 \mathrm{a}$

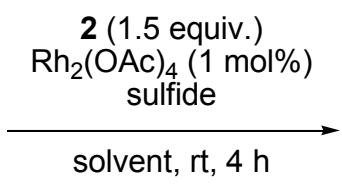

solvent, rt, $4 \mathrm{~h}$

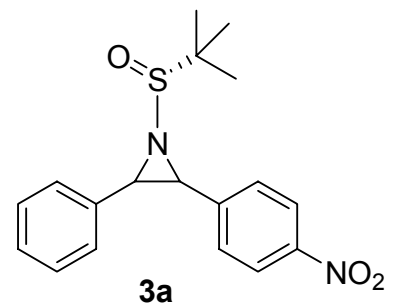

$3 a$

Table 2. Sulfide effect on the sulfur ylide-mediated reaction of imine 1a with PDM 2

\begin{tabular}{llllll}
\hline Entry & Sulfide (equiv.) & Solvent & Trans $:$ cis $^{\mathrm{a}}$ & $\begin{array}{l}\text { D.e. trans- } \\
\left(R_{\mathrm{S}}, 2 R, 3 R\right)-\end{array}$ & $\begin{array}{l}\text { Yield } \\
\mathbf{3 a}^{\mathrm{a}}\end{array}$ \\
\hline 1 & diphenyl sulfide $(0.5)$ & toluene & ----- & ----- & 0 \\
2 & dimethyl sulfide $(0.5)$ & toluene & $75: 25$ & $<5 \%$ & 99 \\
3 & dibutyl sulfide $(0.5)$ & toluene & $67: 33$ & $8 \%$ & 99 \\
4 & diisopropyl sulfide $(0.5)$ & toluene & $54: 46$ & $13 \%$ & $43 \%$ conv. \\
5 & dimethyl sulfide $(0.5)$ & acetonitrile & $71: 29$ & $(61 \%)^{\mathrm{c}}$ & 99 \\
6 & dibutyl sulfide $(0.5)$ & acetonitrile & $67: 33$ & $(54 \%)^{\mathrm{c}}$ & 99 \\
7 & diisopropyl sulfide $(1.0)$ & acetonitrile & $64: 36$ & $(45 \%)^{\mathrm{c}}$ & 96 \\
\hline
\end{tabular}

${ }^{a}$ Determined from the ${ }^{1} \mathrm{H}$ NMR spectrum of the crude product. ${ }^{\mathrm{b}}$ Combined isolated yield of cisand trans-aziridines. ${ }^{\mathrm{c}}\left(R_{\mathrm{S}}, 2 S, 3 S\right)-\mathbf{3 a}$ was the major product. 
As the results show in Table 2, when toluene was used, diphenyl sulfide was found to be ineffective in the reaction, presumably due to the relatively low nucleophilicity of this sulfide, which inhibited its reaction with the metallocarbene intermediate, thus precluding formation of the corresponding sulfur ylide. On the other hand, in the presence of 50 mol\% dimethyl sulfide, the reaction proceeded smoothly and provided aziridines in quantitative yield, albeit with a slightly lower trans/cis ratio and very poor diastereoselectivity between the two trans-aziridines as compared to when THT was used. Use of dibutyl sulfide (DBS) did not improve the trans diastereomeric excess and a slight drop in the trans/cis ratio was also observed. Unfortunately, when the more sterically hindered diisopropyl sulfide was applied, the selectivity between the two trans-aziridines remained low and a further decrease of the trans/cis ratio occurred.

These results of the solvent and sulfide screen revealed the most appropriate combination of solvent and sulfide, as evidenced by the greatest stereoselectivity. Such was also determined from the results obtained with different sulfides when the reactions were performed in acetonitrile. Increasing steric hindrance of the sulfide did not improve the diastereoselectivity between the two trans isomers but rather led to a decrease in the trans/cis ratio. For acetonitrile, the "best" sulfide appeared to be the sterically least hindered dimethyl sulfide. In contrast, when toluene was used, THT offered the highest diastereoselectivity.

Strong evidence has been gathered and it has been well-established that addition of a benzylstabilized sulfur ylide to an imine is under kinetic control, ${ }^{7 \mathrm{e}, 17}$ therefore the irreversible sulfur ylide addition step determines the stereochemistry of the reaction. If the sulfur ylide adopts a transoid approach in its attack upon the imine (vide infra) to minimize steric effects, ${ }^{17}$ then the formation of the anti adduct would be favored over the syn adduct; this rationale is consistent with the observed preference of formation of the trans-aziridines over the cis-aziridines in the reaction (Scheme 1).

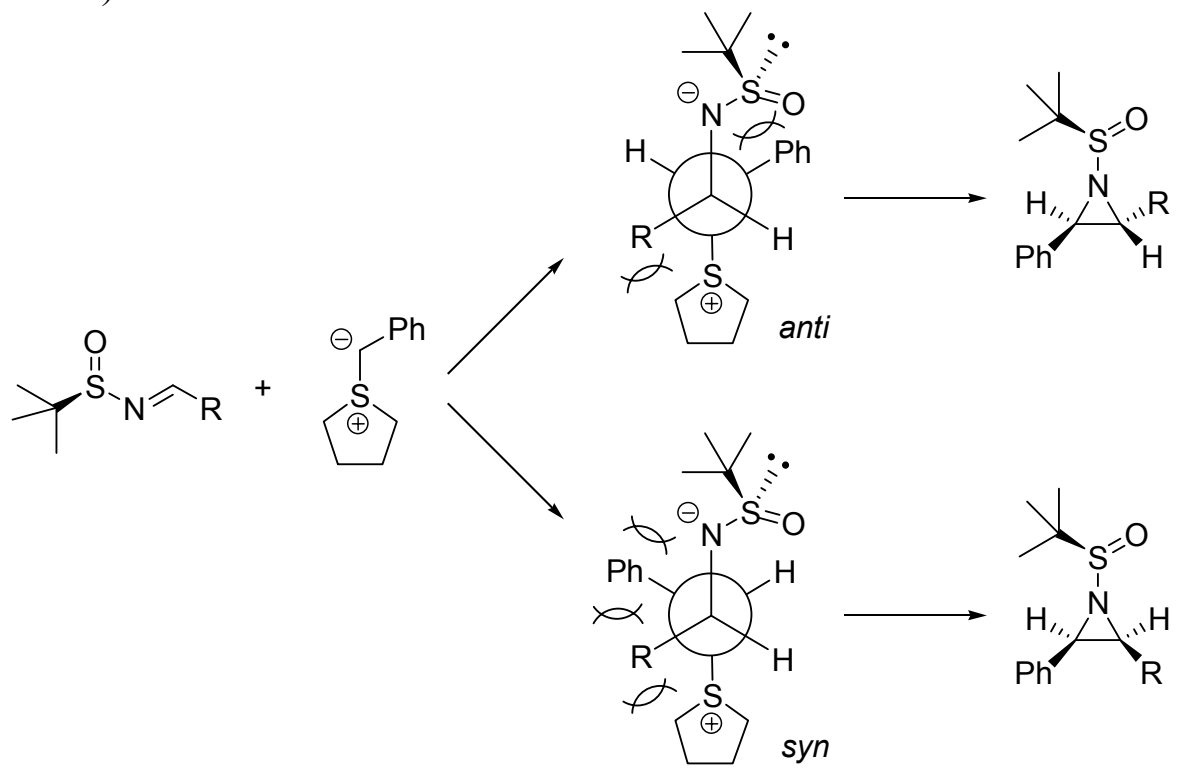

Scheme 1. Benzyl sulfur ylide addition to $\left(R_{\mathrm{S}}\right)$-N-tert-butanesulfinyl imines in anti and syn modes. 
Unfortunately, a satisfactory explanation is still lacking for the dependence of the diastereoselectivity between the two trans isomers upon the solvent and sulfide. In fact, the moderate selectivity observed here is in sharp contrast to the high diastereoselectivities reported by others when sulfur ylides (prepared by deprotonation of sulfonium salts) were employed in related aziridinations. ${ }^{5}$

$N$-tert-butanesulfinyl imines bearing aromatic, aliphatic, and heterocyclic substituents were synthesized and employed in the reaction. Each substrate was tested under two reaction conditions, i.e. with different solvent and sulfide combinations, specifically toluene with THT and acetonitrile with DBS.
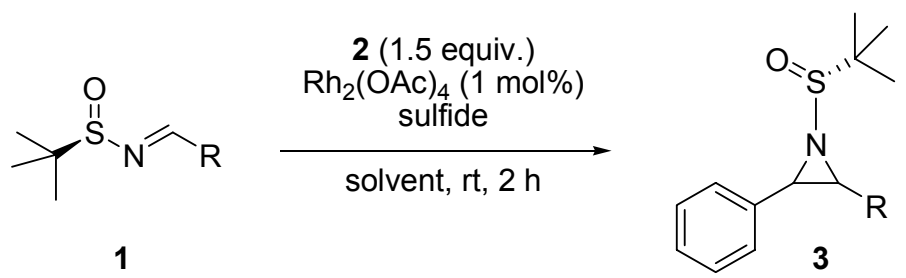

As can be seen in the results listed in Table 3, it was found that most imines, especially those containing electron-donating substituents, generally required an increased loading of the sulfide from $50 \mathrm{~mol} \%$ to 1 equiv. to obtain higher conversions of the imine. This trend was more obvious when acetonitrile was used as the solvent, where the electron-rich imines were particularly less reactive in comparison to their reactions in toluene, as indicated by the poor conversion of the imines in these cases (entries 4, 6, and 12 in Table 3). Interestingly, when the reactions were carried out in toluene, an improvement of the diastereoselectivity of the transaziridines was observed for most of these electron-rich imines as compared to the electrondeficient imines. Transformation of imino ester $1 \mathbf{g}$ to aziridines under the reaction conditions was met with less success. In toluene, a complex mixture was obtained after the reaction, and no aziridine was isolated; in acetonitrile, the major trans isomer, $\left(R_{\mathrm{S}}, 2 R, 3 S\right)-\mathbf{3 g}$, was isolated in only $41 \%$ yield, despite the high diastereoselectivity of the reaction as indicated by the ${ }^{1} \mathrm{H} N \mathrm{NR}$ spectrum of the crude product mixture. The reason for the low yield in this case was not clear. However, based on the complicated ${ }^{1} \mathrm{H}$ NMR spectrum of the crude product, it might be related to an instability of the products under the reaction/work-up conditions. In general, the trans/cis selectivity of the reactions was not substantially affected by the substituents on the imines. One exception was imine 1i bearing the 2-pyridyl group. In this case, one of the cis-aziridines resulted as the major product, which might be attributable to the involvement of the pyridyl nitrogen in complexation to the rhodium catalyst, thus potentially affecting the steric bulk of the imine substrate and the orientation toward reaction with the sulfur ylide. 
Table 3. Study of imine scope

\begin{tabular}{|c|c|c|c|c|c|}
\hline Entry $^{\mathrm{a}}$ & (Imine) $\mathrm{R}$ & Sulfide (equiv.) & $\begin{array}{l}\text { Trans: cis } \\
\mathbf{3}^{\mathrm{b}}\end{array}$ & $\begin{array}{l}\text { D.e. } \\
{\text { trans }-\mathbf{3}^{\mathrm{b}, \mathrm{c}}}\end{array}$ & Yield $^{\mathrm{d}, \mathrm{e}}$ \\
\hline 1 & (1a) $4-\mathrm{NO}_{2}-\mathrm{C}_{6} \mathrm{H}_{4}$ & THT (0.5) & $81: 19$ & $41 \%$ & $99(57)$ \\
\hline 2 & (1a) $4-\mathrm{NO}_{2}-\mathrm{C}_{6} \mathrm{H}_{4}$ & $\operatorname{DBS}(0.5)$ & $67: 33$ & $(54 \%)$ & $99(51)$ \\
\hline 3 & (1b) $4-\mathrm{MeO}-\mathrm{C}_{6} \mathrm{H}_{4}{ }^{\mathrm{f}}$ & THT (1.0) & $89: 11$ & $70 \%$ & $93(70)$ \\
\hline 4 & (1b) $4-\mathrm{MeO}-\mathrm{C}_{6} \mathrm{H}_{4}{ }^{\mathrm{f}}$ & DBS (1.0) & $77: 23$ & $(15 \%)$ & $\sim 48 \%$ conv \\
\hline 5 & (1c) phenyl & THT $(0.5)$ & $86: 14$ & $63 \%$ & $99(70)$ \\
\hline 6 & (1c) phenyl $^{\mathrm{f}}$ & DBS (1.0) & $70: 30$ & $(20 \%)$ & $\sim 50 \%$ conv \\
\hline 7 & (1d) $4-\mathrm{Br}-\mathrm{C}_{6} \mathrm{H}_{4}$ & THT (0.5) & $87: 13$ & $57 \%$ & $99(70)$ \\
\hline 8 & (1d) $4-\mathrm{Br}-\mathrm{C}_{6} \mathrm{H}_{4}{ }^{\mathrm{f}}$ & DBS (1.0) & $69: 31$ & $(36 \%)$ & $99(47)$ \\
\hline 9 & (1e) trans-styryl $\mathrm{f}^{\mathrm{f}}$ & THT (1.0) & $90: 10$ & $70 \%$ & $99(74)$ \\
\hline 10 & (1e) trans-styryl ${ }^{\mathrm{f}}$ & $\operatorname{DBS}(1.0)$ & $83: 17$ & $14 \%$ & $85(39)$ \\
\hline 11 & (1f) $n$-pentyl $\mathrm{f}^{\mathrm{f}}$ & THT (1.0) & $87: 13$ & $63 \%$ & $99(69)$ \\
\hline 12 & (1f) $n$-pentyl $\mathrm{l}^{\mathrm{f}}$ & $\operatorname{DBS}(1.0)$ & $69: 31$ & $(18 \%)$ & $\sim 40 \%$ conv. \\
\hline 13 & (1g) ethoxycarbonyl & THT $(0.5)$ & $\mathrm{Nd}^{\mathrm{g}}$ & $\mathrm{Nd}^{\mathrm{g}}$ & $\mathrm{Nd}^{\mathrm{g}}$ \\
\hline 14 & (1g) ethoxycarbonyl & DBS (1.0) & $90: 10$ & $(86 \%)$ & $(41)$ \\
\hline 15 & (1h) 2-furyl & THT $(0.5)$ & $81: 19$ & $40 \%$ & $99(56)$ \\
\hline 16 & (1h) 2 -furyl ${ }^{\mathrm{f}}$ & $\operatorname{DBS}(1.0)$ & $59: 41$ & $(29 \%)$ & $70(24)$ \\
\hline 17 & (1i) 2-pyridyl & THT (0.5) & $37: 63$ & $(t) 58 ;(c) 51$ & $(t) 28 ;(c) 47$ \\
\hline 18 & (1i) 2-pyridyl & DBS (1.0) & $29: 71$ & $(t) 71 ;(c) 49$ & $(t) 23 ;(c) 54$ \\
\hline
\end{tabular}

${ }^{\mathrm{a}}$ Toluene was used together with THT; acetonitrile was used together with DBS. ${ }^{\mathrm{b}}$ Determined from the ${ }^{1} \mathrm{H}$ NMR spectrum of the crude product. ${ }^{\mathrm{c}}$ The d.e. in parentheses refers to the isomer in which the carbon bearing the phenyl group has an $(S)$ configuration. ${ }^{\mathrm{d}}$ Combined isolated yield of cis- and trans-aziridines. ${ }^{\mathrm{e}}$ In parentheses is the isolated yield of the major isomer. ${ }^{\mathrm{f}} 2$ equiv. PDM was used. ${ }^{\mathrm{g}}$ Not determined.

\section{Conclusions}

In summary, we have found that asymmetric $N$-tert-butanesulfinyl imines, which were generally unreactive toward diazo compounds such as EDA, TMSD, and PDM in the presence of Lewis acids, could readily react with PDM via a sulfur ylide-mediated route to form aziridines. The sulfur ylides were prepared in-situ from the reaction of sulfides with a metallocarbene intermediate, which was generated by a rhodium-catalyzed decomposition of PDM. The reactions were found to provide aziridines with quantitative yields in most cases wherein the 2,3trans-aziridines were the major isomers. The diastereoselectivity between the two trans isomers 
showed a substantial dependence upon the solvent and sulfide employed in the reaction. With most of the imines tested, toluene in combination with tetrahydrothiophene gave the highest selectivity for one of the trans-aziridines, whereas acetonitrile used together with dibutyl sulfide selectively gave the other.

\section{Experimental Section}

General. Anhydrous acetonitrile and dichloromethane were distilled from calcium hydride. Anhydrous toluene and tetrahydrofuran were distilled from sodium. Unless otherwise stated, commercial reagents were used without further purification. Phenyldiazomethane $\mathbf{2}$ was prepared following the literature procedure ${ }^{20}$ and stored at $-80{ }^{\circ} \mathrm{C}$ as a dichloromethane solution, ca. 2.5 3.5 M (concentration measured by ${ }^{1} \mathrm{H}$ NMR using $p$-nitrotoluene as an internal standard). $\left(R_{\mathrm{S}}\right)$ - $N$-tert-butanesulfinamide ${ }^{21}$ and $\left(R_{\mathrm{S}}\right)$ - $N$-tert-butanesulfinyl imines 1a-1i were synthesized according to the literature procedures. ${ }^{22,23}$ Melting points were measured on an Electrothermal capillary melting point apparatus and were uncorrected. IR spectra were recorded on a Nicolet IR100 FT-IR spectrometer. ${ }^{1} \mathrm{H}$ NMR and ${ }^{13} \mathrm{C}$ NMR spectra were recorded on a Varian Unity Plus 300 or a Varian Mercury Plus 300 spectrometer. Low temperature $\left(-20{ }^{\circ} \mathrm{C}\right){ }^{1} \mathrm{H}$ NMR and ${ }^{13} \mathrm{C}$ NMR spectra were recorded on a Varian Unity Inova $500 \mathrm{MHz}$ Spectrometer. Tetramethylsilane (TMS, $\delta=0.00)$ served as a shift reference for ${ }^{1} \mathrm{H}$ NMR spectra and $\mathrm{CDCl}_{3}(\delta=77.16)$ was used as a shift reference for ${ }^{13} \mathrm{C}$ NMR spectra. Elemental analyses were performed by Columbia Analytical Services, Inc. Tucson, AZ. Electron impact mass spectrometry (EI-MS) was performed on a Thermo Finnigan GCQ-Plus Mass Spectrometer. Single crystal X-ray crystallographic analysis was performed on a Rigaku SCX mini diffractometer equipped with a TEC-50 cryostream and employing Mo-K $\alpha(\lambda=0.71073 \AA)$ irradiation from a sealed x-ray source. Flash chromatography was performed using Silicycle UltraPure Flash Silica Gel, $60 \AA$, 40-63 $\mu \mathrm{m}$. Thin layer chromatography (TLC) was performed using EMD HPTLC plates, silica gel $60, \mathrm{~F}_{254}$. All reaction vessels were flame-dried under vacuum and filled with nitrogen prior to use.

\section{General procedures for aziridine synthesis and purification}

At room temperature, into a flame-dried $50 \mathrm{~mL}$ Schlenk flask charged with imine $1 \mathrm{a}(127 \mathrm{mg}$, $0.5 \mathrm{mmol})$ and $\mathrm{Rh}_{2}(\mathrm{OAc})_{4}(2.2 \mathrm{mg}, 0.005 \mathrm{mmol})$ was added toluene $(2 \mathrm{~mL})$ followed by tetrahydrothiophene $(22 \mu \mathrm{L}, 0.25 \mathrm{mmol})$. The mixture was stirred at this temperature for $5 \mathrm{~min}$ before a toluene solution $(1 \mathrm{~mL})$ of $2(0.75 \mathrm{mmol})$ was added via a syringe pump over a period of 1 hour. Solvents were then removed under reduced pressure, and the crude was subjected to silica gel chromatography with ethyl acetate/hexanes $(5: 95$ - 30:70) as the eluent. Two trans isomers of 3a were isolated as their pure forms, respectively; two cis isomers of $\mathbf{3 a}$ were obtained as a mixture. Yield of major $\left(R_{\mathrm{S}}, 2 R, 3 R\right)-3 \mathbf{a}: 57 \%$; combined yield of all four isomers: quant. Similar procedures were followed when other imines were used. 
$\left(\boldsymbol{R}_{\mathrm{S}}, 2 R, 3 R\right)-1-\left(\right.$ tert-Butanesulfinyl)-2-(4-nitrophenyl)-3-phenylaziridine $\quad\left(\left(\boldsymbol{R}_{\mathrm{S}}, \mathbf{2 R}, \mathbf{3 R}\right)-3 \mathrm{a}\right)$. White crystals; m.p. $156^{\circ} \mathrm{C}$, decomp; $\mathrm{R}_{f} 0.25$ (hexanes/ethyl acetate, $70: 30$ ); $[\alpha]_{D}^{23}=+21.6^{\circ}$ (c 0.5, $\mathrm{CHCl}_{3}$ ); IR (film): 2982, 1602, 1519, 1345, 1086, $860 \mathrm{~cm}^{-1} ; \mathrm{MS} \mathrm{m} / z$ (\%): 288 (16), 271 (17), 239 (28), 225 (100), 193 (46), 178 (69), 165 (78), 136 (27), 89 (26); ${ }^{1} \mathrm{H} \mathrm{NMR} \mathrm{(300} \mathrm{MHz,} \mathrm{CDCl} 3$ ) $\delta 8.26(\mathrm{~d}, J=8.7 \mathrm{~Hz}, 2 \mathrm{H}), 7.66(\mathrm{~d}, J=8.7 \mathrm{~Hz}, 2 \mathrm{H}), 7.53-7.33(\mathrm{~m}, 5 \mathrm{H}), 3.91(\mathrm{~d}, J=3.9 \mathrm{~Hz}, 1 \mathrm{H})$, $3.88(\mathrm{~d}, J=3.9 \mathrm{~Hz}, 1 \mathrm{H}), 1.20(\mathrm{~s}, 9 \mathrm{H}) ;{ }^{13} \mathrm{C} \mathrm{NMR}\left(75 \mathrm{MHz}, \mathrm{CDCl}_{3}\right) \delta 148.02,142.11,133.17$, $129.09,129.06,128.90,128.43,124.00,57.33,49.16,46.94,22.39$; Anal. Calcd. for $\mathrm{C}_{18} \mathrm{H}_{20} \mathrm{~N}_{2} \mathrm{O}_{3} \mathrm{~S}$ : C, 62.77; H, 5.85; N, 8.13. Found: C, 62.62; H, 6.00; N, 8.00.

$\left(\boldsymbol{R}_{\mathrm{S}}, 2 S, 3 S\right)-1-\left(\right.$ tert-Butanesulfinyl)-2-(4-nitrophenyl)-3-phenylaziridine $\quad\left(\left(\boldsymbol{R}_{\mathrm{S}}, 2 S, 3 S\right)-3 \mathrm{a}\right)$. White crystals; m.p. $123-5^{\circ} \mathrm{C}$; $\mathrm{R}_{f} 0.50$ (hexanes/ethyl acetate, 70:30); $[\alpha]_{D}^{23}=-98.0^{\circ}$ (c 0.5 , $\mathrm{CHCl}_{3}$ ); IR (film): 2981, 1603, 1522, 1346, 1074, $860 \mathrm{~cm}^{-1}$; MS m/z (\%): 288 (12), 271 (10), 240 (44), 225 (100), 193 (48), 178 (63), 165 (57), 136 (26), 89 (25); ${ }^{1} \mathrm{H}$ NMR (300 MHz, $\left.\mathrm{CDCl}_{3}, \mathrm{rt}\right) \delta$ $8.25(\mathrm{~d}, J=8.7 \mathrm{~Hz}, 2 \mathrm{H}), 7.63(\mathrm{~d}, J=7.5 \mathrm{~Hz}, 2 \mathrm{H}), 7.54-7.32(\mathrm{~m}, 5 \mathrm{H}), 4.27$ (bs, 1H), 3.75 (bs, $1 \mathrm{H}), 1.15(\mathrm{~s}, 9 \mathrm{H}) ;{ }^{1} \mathrm{H}$ NMR $\left(500 \mathrm{MHz}, \mathrm{CDCl}_{3},-20{ }^{\circ} \mathrm{C}\right) \delta 8.31-8.23(\mathrm{~m}, 2 \mathrm{H}), 7.72$ and $7.60(\mathrm{~d}, J$ $=8.5 \mathrm{~Hz}, 2 \mathrm{H}) ; 7.54-7.35(\mathrm{~m}, 5 \mathrm{H}) ; 4.36$ and $4.30(\mathrm{~d}, J=4.0 \mathrm{~Hz}, 1 \mathrm{H}) ; 3.71$ and $3.70(\mathrm{~d}, J=4.0$ $\mathrm{Hz}, 1 \mathrm{H}) ; 1.14(\mathrm{~s}, 9 \mathrm{H}) ;{ }^{13} \mathrm{C} \mathrm{NMR}\left(125 \mathrm{MHz}, \mathrm{CDCl}_{3},-20{ }^{\circ} \mathrm{C}\right) \delta 147.46,147.21,145.03,139.98$, $136.05,131.37,130.70,129.46,129.02,128.79,128.53,128.22,127.53,126.63,124.02,123.53$, 57.50. 57.25. 51.73. 49.51. 36.20. 35.36. 22.50. 22.46; Anal. Calcd. for $\mathrm{C}_{18} \mathrm{H}_{20} \mathrm{~N}_{2} \mathrm{O}_{3} \mathrm{~S}: \mathrm{C}, 62.77$; H, 5.85; N, 8.13. Found: C, 63.21; H, 5.95; N, 7.79.

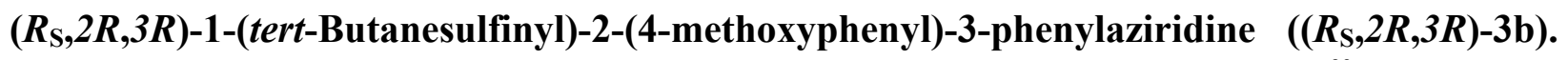
White crystals; m.p. $120{ }^{\circ} \mathrm{C}$, decomp.; $\mathrm{R}_{f} 0.24$ (hexanes/ethyl acetate, 70:30); $[\alpha]_{D}^{23}=+14.0^{\circ}$ (c 0.5, $\mathrm{CHCl}_{3}$ ); IR (film): 2959, 1610, 1516, 1254, 1081, $834 \mathrm{~cm}^{-1} ; \mathrm{MS} \mathrm{m} / z$ (\%): 272 (14), 224 (100), 210 (65), 197 (26), 166 (46), 137 (46), 121 (44), 91 (23); ${ }^{1} \mathrm{H}$ NMR (300 MHz, $\left.\mathrm{CDCl}_{3}\right) \delta$ $7.50-7.28(\mathrm{~m}, 7 \mathrm{H}), 6.92(\mathrm{~d}, J=8.7 \mathrm{~Hz}, 2 \mathrm{H}), 3.80(\mathrm{~s}, 3 \mathrm{H}), 3.79(\mathrm{~s}, 2 \mathrm{H}), 1.18(\mathrm{~s}, 9 \mathrm{H}) ;{ }^{13} \mathrm{C} \mathrm{NMR}$ $\left(75 \mathrm{MHz}, \mathrm{CDCl}_{3}\right) \delta 159.90,134.90,130.04,128.75,128.48,127.89,125.52,114.09,56.82$, 55.36, 48.79, 47.30, 22.43; Anal. Calcd. for $\mathrm{C}_{19} \mathrm{H}_{23} \mathrm{NO}_{2} \mathrm{~S}$ : C, 69.27; H, 7.04; N, 4.25. Found: C, $69.06 ; \mathrm{H}, 7.02 ; \mathrm{N}, 4.05$.

$\left(R_{\mathrm{S}}, 2 R, 3 R\right)-1-\left(\right.$ tert-Butanesulfinyl)-2,3-diphenylaziridine $\left(\left(R_{\mathrm{S}}, 2 R, 3 R\right)-3 \mathrm{c}\right)$. White crystals; m.p. $157{ }^{\circ} \mathrm{C}$, decomp.; $\mathrm{R}_{f} 0.32$ (hexanes/ethyl acetate, 70:30); $[\alpha]_{D}^{23}=+3.6^{\circ}$ (c $0.5, \mathrm{CHCl}_{3}$ ); IR (film): 2984, 1449, $1080 \mathrm{~cm}^{-1}$; MS m/z (\%): 194 (22), 180 (100), 165 (23); ${ }^{1} \mathrm{H}$ NMR (300 MHz, $\left.\mathrm{CDCl}_{3}\right) \delta$ 7.56-7.44 (m, 4H), 7.44-7.31 (m, 6H), $3.83(\mathrm{~s}, 2 \mathrm{H}), 1.10(\mathrm{~s}, 9 \mathrm{H}) ;{ }^{3} \mathrm{C} \mathrm{NMR}(75 \mathrm{MHz}$, $\left.\mathrm{CDCl}_{3}\right) \delta 134.26,134.26,128.73,128.73,128.64,128.64,128.36,128.36,56.96,48.24,48.24$, 22.44; Anal. Calcd. for $\mathrm{C}_{18} \mathrm{H}_{21} \mathrm{NOS}$ : C, 72.20; H, 7.07; N, 4.68. Found: C, 71.20; H, 6.90; N, 4.59 .

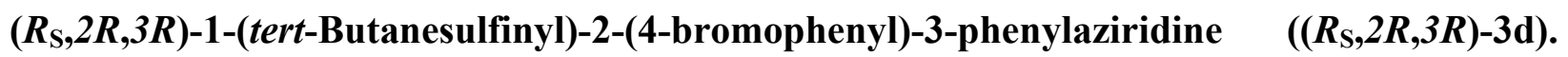
White crystals; m.p. $152{ }^{\circ} \mathrm{C}$, decomp.; $\mathrm{R}_{f} 0.35$ (hexanes/ethyl acetate, 70:30); $[\alpha]_{D}^{23}=+12.0^{\circ}$ (c 0.5, $\mathrm{CHCl}_{3}$ ); IR (film): 2982, 1492, 1078, $880 \mathrm{~cm}^{-1}$; MS m/z (\%): 272 (10), 258 (43), 193 (28), 179 (100), 166 (54), 116 (27), 89 (32); ${ }^{1} \mathrm{H} \mathrm{NMR}\left(300 \mathrm{MHz}, \mathrm{CDCl}_{3}\right.$ ) $\delta$ 7.57-7.30 (m, 9H), 3.78 (bs, 2H), $1.18(\mathrm{~s}, 9 \mathrm{H}) ;{ }^{13} \mathrm{C}$ NMR $\left(75 \mathrm{MHz}, \mathrm{CDCl}_{3}\right) \delta 133.95,133.26,131.89,130.04,128.78$, 
128.75, 128.20, 122.78, 57.04, 48.10, 47.71, 22.39; Anal. Calcd. for $\mathrm{C}_{18} \mathrm{H}_{20}$ BrNOS: C, 57.14; $\mathrm{H}$, 5.33 ; N, 3.70. Found: C, 57.08; H, 5.25; N, 3.61.

$\left(R_{\mathrm{S}}, 2 S, 3 S\right)-1-\left(\right.$ tert-Butanesulfinyl)-2-(4-bromophenyl)-3-phenylaziridine $\quad\left(\left(R_{\mathrm{S}}, 2 S, 3 S\right)-3 \mathrm{~d}\right)$. White crystals; m.p. $112-4{ }^{\circ} \mathrm{C} ; \mathrm{R}_{f} 0.60$ (hexanes/ethyl acetate, $70: 30$ ); $[\alpha]_{D}^{23}=-86.6^{\circ}$ (c 0.5 , $\mathrm{CHCl}_{3}$ ); IR (film): 2981, 1490, 1074, $899 \mathrm{~cm}^{-1}$; MS m/z (\%): 272 (20), 258 (33), 193 (34), 179 (100), 166 (70), 116 (36), 89 (35); ${ }^{1} \mathrm{H} \mathrm{NMR}\left(300 \mathrm{MHz}, \mathrm{CDCl}_{3}, \mathrm{rt}\right) \delta 7.50$ (d, $\left.J=8.4 \mathrm{~Hz}, 2 \mathrm{H}\right)$, 7.48-7.27 (m, 7H), 4.18 (bs, 1H), 3.63 (bs, 1H), 1.14 (s, 9H); ${ }^{1} \mathrm{H}$ NMR (500 MHz, $\mathrm{CDCl}_{3,}-20$ $\left.{ }^{\circ} \mathrm{C}\right) \delta$ 7.54-7.48 (m, 3H), 7.45-7.32 (m, 5H), $7.30(\mathrm{~d}, J=8.5 \mathrm{~Hz}, 1 \mathrm{H}), 4.24(\mathrm{~d}, J=4.0 \mathrm{~Hz}, 1 \mathrm{H})$, 3.63 and $3.60(\mathrm{~d}, J=4.5 \mathrm{~Hz}, 1 \mathrm{H}) ; 1.15$ and $1.14(\mathrm{~s}, 9 \mathrm{H}) ;{ }^{13} \mathrm{C} \mathrm{NMR}\left(125 \mathrm{MHz}, \mathrm{CDCl}_{3},-20{ }^{\circ} \mathrm{C}\right) \delta$ $136.65,136.23,131.84,131.66,131.45,131.22$, 131.17, 129.46, 128.73, 128.63, 128.38, 128.32, 127.90, 126.61, 122.79, 121.57, 57.16, 57.09, 51.00, 50.00, 35.78, 35.42, 22.50, 22.50; Anal. Calcd. for $\mathrm{C}_{18} \mathrm{H}_{20}$ BrNOS: C, 57.14; H, 5.33; N, 3.70. Found: C, 57.58; H, 5.36; N, 3.67.

$\left(R_{\mathrm{S}}, 2 R, 3 R, E\right)-1-(t e r t-B u t a n e s u l f i n y l)-2-p h e n y l-3-s t y r y l a z i r i d i n e \quad\left(\left(R_{\mathrm{S}}, 2 R, 3 R\right)-3 \mathrm{e}\right) . \quad$ White crystals; m.p. $103{ }^{\circ} \mathrm{C}$, decomp.; $\mathrm{R}_{f} 0.55$ (hexanes/ethyl acetate, $70: 30$ ); $[\alpha]_{D}^{23}=-103.2^{\circ}$ (c 0.5 , $\mathrm{CHCl}_{3}$ ); IR (film): 2982, 1602, 1455, $1076 \mathrm{~cm}^{-1}$; MS m/z (\%): 220 (32), 206 (13), 115 (100), 91 (24); ${ }^{1} \mathrm{H}$ NMR $\left(300 \mathrm{MHz}, \mathrm{CDCl}_{3}\right) \delta$ 7.45-7.19 (m, 10H), $6.70(\mathrm{bs}, 1 \mathrm{H}), 6.77-6.60(\mathrm{~m}, 1 \mathrm{H}), 3.68$ $(\mathrm{d}, J=3.6 \mathrm{~Hz}, 1 \mathrm{H}), 3.23(\mathrm{ddd}, J=7.2 \mathrm{~Hz}, J=3.3 \mathrm{~Hz}, J=1.2 \mathrm{~Hz}, 1 \mathrm{H}), 1.30(\mathrm{~s}, 9 \mathrm{H}) ;{ }^{13} \mathrm{C}$ NMR $\left(75 \mathrm{MHz}, \mathrm{CDCl}_{3}\right) \delta 136.94,136.46,135.22,128.77,128.72,128.10,128.03,126.66,126.45$, 125.21, 57.54, 54.93, 44.55, 23.28; Anal. Calcd. for $\mathrm{C}_{20} \mathrm{H}_{23} \mathrm{NOS}$ : C, 73.81; H, 7.12; N, 4.30. Found: C, 73.42; H, 7.07; N, 4.10.

$\left(R_{\mathrm{S}}, 2 S, 3 S, E\right)-1-\left(\right.$ tert-Butanesulfinyl)-2-phenyl-3-styrylaziridine $\quad\left(\left(R_{\mathrm{S}}, 2 S, 3 S\right)-3 \mathrm{e}\right) . \quad$ White crystals; m.p. $87-9{ }^{\circ} \mathrm{C} ; \mathrm{R}_{f} 0.60$ (hexanes/ethyl acetate, 70:30); $[\alpha]_{D}^{23}=-238.4^{\circ}\left(\mathrm{c} 0.5, \mathrm{CHCl}_{3}\right.$ ); IR (film): 2981, 1602, 1455, $1072 \mathrm{~cm}^{-1}$; MS m/z (\%): 220 (24), 206 (8), 115 (100), 91 (19); ${ }^{1} \mathrm{H}$ NMR $\left(300 \mathrm{MHz}, \mathrm{CDCl}_{3}\right.$, rt) $\delta$ 7.44-7.20 (m, 10H), $6.79(\mathrm{~d}, J=15.6 \mathrm{~Hz}, 1 \mathrm{H}), 6.37$ (dd, $J=15.6$ $\mathrm{Hz}, J=9.3 \mathrm{~Hz}, 1 \mathrm{H}), 3.83(\mathrm{~d}, J=3.6 \mathrm{~Hz}, 1 \mathrm{H}), 3.23(\mathrm{~d}, J=7.2 \mathrm{~Hz}, 1 \mathrm{H}), 1.19(\mathrm{~s}, 9 \mathrm{H})$; ${ }^{1} \mathrm{H}$ NMR $\left(500 \mathrm{MHz}, \mathrm{CDCl}_{3},-20{ }^{\circ} \mathrm{C}\right) \delta$ 7.45-7.41 (m, 2H), 7.40-7.36 (m, 2H), 7.35-7.30 (m, 5H), 7.29-7.24 $(\mathrm{m}, 1 \mathrm{H}), 6.79(\mathrm{~d}, J=15.5 \mathrm{~Hz}, 1 \mathrm{H}), 6.38(\mathrm{dd}, J=15.5 \mathrm{~Hz}, J=9.5 \mathrm{~Hz}, 1 \mathrm{H}), 3.85(\mathrm{~d}, J=3.5 \mathrm{~Hz}$, $1 \mathrm{H}), 3.23(\mathrm{dd}, J=9.5 \mathrm{~Hz}, J=3.5 \mathrm{~Hz}, 1 \mathrm{H}), 1.19(\mathrm{~s}, 9 \mathrm{H}) ;{ }^{13} \mathrm{C} \mathrm{NMR}\left(125 \mathrm{MHz}, \mathrm{CDCl}_{3},-20{ }^{\circ} \mathrm{C}\right) \delta$ $136.72,136.50,135.75,128.58,128.50,127.98,127.73,126.47,126.39$, 123.51, 57.21, 50.91, 38.54, 22.62; Anal. Calcd. for $\mathrm{C}_{20} \mathrm{H}_{23} \mathrm{NOS}$ : C, 73.81; H, 7.12; N, 4.30. Found: C, 73.36; H, 7.16; $\mathrm{N}, 4.10$.

$\left(\boldsymbol{R}_{\mathrm{S}}, 2 \boldsymbol{R}, \mathbf{3 R}\right)-1-\left(\right.$ tert-Butanesulfinyl)-2-(n-pentyl)-3-phenylaziridine $\left(\left(\boldsymbol{R}_{\mathrm{S}}, \mathbf{2} \boldsymbol{R}, \mathbf{3 R}\right)-\mathbf{3 f}\right)$. Colorless oil; $\mathrm{R}_{f} 0.55$ (hexanes/ethyl acetate, 70:30); $[\alpha]_{D}^{23}=-141.6^{\circ}$ (c $0.5, \mathrm{CHCl}_{3}$ ); IR (film): 2928, 2860, 1458, 1361, $1099 \mathrm{~cm}^{-1}$; MS m/z (\%): 237 (9), 174 (42), 117 (36), 104 (100), 91 (43); ${ }^{1} \mathrm{H}$ NMR $\left(300 \mathrm{MHz}, \mathrm{CDCl}_{3}\right) \delta$ 7.39-7.20 (m, 5H), $3.13(\mathrm{~d}, J=3.9 \mathrm{~Hz}, 1 \mathrm{H}), 2.65-2.55(\mathrm{~m}, 1 \mathrm{H}), 2.35-$ $2.21(\mathrm{~m}, 1 \mathrm{H}), 1.90-1.73(\mathrm{~m}, 1 \mathrm{H}), 1.69-1.41(\mathrm{~m}, 2 \mathrm{H}), 1.40-1.28(\mathrm{~m}, 4 \mathrm{H}), 1.21(\mathrm{~s}, 9 \mathrm{H}), 0.88(\mathrm{t}, J=$ $6.9 \mathrm{~Hz}, 3 \mathrm{H}) ;{ }^{13} \mathrm{C} \mathrm{NMR}\left(75 \mathrm{MHz}, \mathrm{CDCl}_{3}\right) \delta 137.34,128.75,127.92,126.39,56.98,50.91,46.60$, 31.62, 29.19, 27.85, 22.62, 22.40, 14.10; Anal. Calcd. for $\mathrm{C}_{17} \mathrm{H}_{27} \mathrm{NOS}$ : C, 69.58; H, 9.27; N, 4.77. Found: C, 69.29; H, 9.26; N, 4.55. 
$\left(R_{\mathrm{S}}, 2 R, 3 S\right)$-Ethyl 1-(tert-butanesulfinyl)-3-phenylaziridine-2-carboxylate $\quad\left(\left(R_{\mathrm{S}}, 2 R, 3 S\right)-3 \mathrm{~g}\right)$. White crystals; m.p. $62{ }^{\circ} \mathrm{C}$, decomp.; $\mathrm{R}_{f} 0.42$ (hexanes/ethyl acetate, 70:30); $[\alpha]_{D}^{23}=-90.8^{\circ}$ (c 0.5, $\mathrm{CHCl}_{3}$ ); IR (film): 2982, 1741, 1194, $1078 \mathrm{~cm}^{-1}$; MS m/z (\%): 176 (78), 148 (83), 131 (100), 117 (66), 104 (23), 91 (34); ${ }^{1} \mathrm{H}$ NMR (300 MHz, CDCl 3 rt) $\delta$ 7.43-7.28 (m, 5H), 4.28 (dq, $J=$ $7.2 \mathrm{~Hz}, J=1.2 \mathrm{~Hz}, 1 \mathrm{H}), 3.92(\mathrm{~d}, J=3.9 \mathrm{~Hz}, 1 \mathrm{H}), 3.22(\mathrm{bs}, 1 \mathrm{H}), 1.32(\mathrm{t}, J=7.2 \mathrm{~Hz}, 3 \mathrm{H}), 1.19$ (s, 9H); ${ }^{1} \mathrm{H}$ NMR $\left(500 \mathrm{MHz}, \mathrm{CDCl}_{3},-20{ }^{\circ} \mathrm{C}\right) \delta$ 7.49-7.28 (m, 5H), 4.36-4.22 (m, 2H), 3.95 and 3.90 (bs and $\mathrm{d}, J=2.1 \mathrm{~Hz}, 1 \mathrm{H}), 3.16$ and $2.14(\mathrm{~d}$ and $\mathrm{bs}, J=2.1 \mathrm{~Hz}, 1 \mathrm{H}), 1.33(\mathrm{t}, J=7.2 \mathrm{~Hz}, 3 \mathrm{H})$, 1.21 and 1.19 (s, 9H); ${ }^{13} \mathrm{C}$ NMR $\left(125 \mathrm{MHz}, \mathrm{CDCl}_{3},-20{ }^{\circ} \mathrm{C}\right) \delta 169.20,167.35,135.74,130.59$, 129.66, 129.18, 128.74, 128.58, 128.42, 126.72, 62.14, 61.99, 57.68, 57.57, 46.25, 45.84, 37.83, 32.29, 22.51, 22.35, 14.26, 14.15; Anal. Calcd. for $\mathrm{C}_{15} \mathrm{H}_{21} \mathrm{NO}_{3} \mathrm{~S}: \mathrm{C}, 60.99 ; \mathrm{H}, 7.17 ; \mathrm{N}, 4.74$. Found: C, 61.57; H, 6.96; N, 4.78 .

$\left(R_{\mathrm{S}}, 2 S, 3 R\right)$-1-(tert-Butanesulfinyl)-2-(furan-2-yl)-3-phenylaziridine $\left(\left(R_{\mathrm{S}}, 2 S, 3 R\right)-3 \mathrm{~h}\right)$. White crystals; m.p. $109{ }^{\circ} \mathrm{C}$, decomp; $\mathrm{R}_{f} 0.25$ (hexanes/ethyl acetate, 70:30); $[\alpha]_{D}^{23}=-47.8^{\circ}$ (c 0.5, $\mathrm{CHCl}_{3}$ ); IR (film): 2987, 1496, 1460, 1080, $874 \mathrm{~cm}^{-1}$; MS m/z (\%): 184 (88), 170 (100), 157 (20), 141 (53), 129 (33), 116 (44); ${ }^{1} \mathrm{H}$ NMR (300 MHz, $\mathrm{CDCl}_{3}$ ) $\delta 7.47$ (bs, 1H), 7.43-7.28 (m, $5 \mathrm{H}), 6.60-6.50(\mathrm{~m}, 1 \mathrm{H}), 6.47-6.37(\mathrm{~m}, 1 \mathrm{H}), 3.95(\mathrm{~d}, J=3.3 \mathrm{~Hz}, 1 \mathrm{H}), 3.73(\mathrm{~d}, J=3.3 \mathrm{~Hz}, 1 \mathrm{H})$, $1.21(\mathrm{~s}, 9 \mathrm{H}) ;{ }^{13} \mathrm{C}$ NMR $\left(75 \mathrm{MHz}, \mathrm{CDCl}_{3}\right) \delta 146.94,143.24,135.60,128.85,128.43,126.76$, 111.89, 111.25, 57.05, 45.32, 43.41, 22.28; Anal. Calcd. for $\mathrm{C}_{16} \mathrm{H}_{19} \mathrm{NO}_{2} \mathrm{~S}: \mathrm{C}, 66.41 ; \mathrm{H}, 6.62 ; \mathrm{N}$, 4.84. Found: C, 63.68; H, 6.74; N, 4.49 .

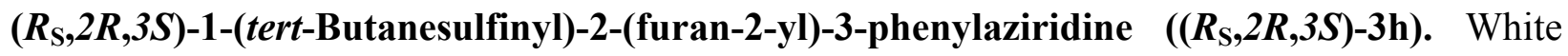
crystals; m.p. $74-6{ }^{\circ} \mathrm{C} ; \mathrm{R}_{f} 0.50$ (hexanes/ethyl acetate, 70:30); $[\alpha]_{D}^{23}=-124.0^{\circ}\left(\mathrm{c} 0.5, \mathrm{CHCl}_{3}\right) ; \mathrm{IR}$ (film): 2982, 1498, 1458, 1074, $879 \mathrm{~cm}^{-1}$; MS m/z (\%): 184 (63), 170 (100), 157 (18), 141 (58), 129 (34), 116 (42); ${ }^{1} \mathrm{H}$ NMR (300 MHz, CDCl 3 , rt) $\delta 7.44$ (bs, $\left.1 \mathrm{H}\right), 7.42-7.28$ (m, 5H), 6.55-6.47 $(\mathrm{m}, 1 \mathrm{H}), 6.44-6.37(\mathrm{~m}, 1 \mathrm{H}), 4.16(\mathrm{~d}, J=3.9 \mathrm{~Hz}, 1 \mathrm{H}), 3.68(\mathrm{bs}, 1 \mathrm{H}), 1.16(\mathrm{~s}, 9 \mathrm{H}) ;{ }^{1} \mathrm{H}$ NMR $(500$ $\left.\mathrm{MHz}, \mathrm{CDCl}_{3},-20{ }^{\circ} \mathrm{C}\right) \delta 7.48(\mathrm{bs}, 1 \mathrm{H}), 7.43-7.31(\mathrm{~m}, 5 \mathrm{H}), 6.57-6.52(\mathrm{~m}, 1 \mathrm{H}), 6.44(\mathrm{bs}, 1 \mathrm{H}), 4.38$ and 4.20 (bs and $\mathrm{d}, J=4.0 \mathrm{~Hz}, 1 \mathrm{H}$ ), 4.12 and 3.62 (bs and $\mathrm{d}, J=4.0 \mathrm{~Hz}, 1 \mathrm{H}), 1.16(\mathrm{~s}, 9 \mathrm{H}) ;{ }^{13} \mathrm{C}$ NMR $\left(125 \mathrm{MHz}, \mathrm{CDCl}_{3},-20{ }^{\circ} \mathrm{C}\right) \delta 147.16,143.31,136.44,128.75,128.14,126.85,111.07$, 110.69, 57.44, 43.14, 36.60, 22.61; Anal. Calcd. for $\mathrm{C}_{16} \mathrm{H}_{19} \mathrm{NO}_{2} \mathrm{~S}: \mathrm{C}, 66.41 ; \mathrm{H}, 6.62$; N, 4.84 . Found: C, 64.75; H, 6.56; N, 4.46 .

$\left(R_{\mathrm{S}}, 2 R, 3 S\right)$-1-(tert-Butanesulfinyl)-2-(2-pyridyl)-3-phenylaziridine $\left(\left(R_{\mathrm{S}}, 2 R, 3 S\right)-3 \mathrm{i}\right)$.

White crystals; m.p. $121-3{ }^{\circ} \mathrm{C} ; \mathrm{R}_{f} 0.16$ (hexanes/ethyl acetate, $70: 30$ ); $[\alpha]_{D}^{23}=-102.0^{\circ}$ (c 0.5 , $\mathrm{CHCl}_{3}$ ); IR (film): 2982, 1590, 1475, 1437, 1073, 901, $771 \mathrm{~cm}^{-1}$; MS m/z (\%): 195 (30), 182 (100), 167 (15), 92 (50); ${ }^{1} \mathrm{H}$ NMR $\left(300 \mathrm{MHz}, \mathrm{CDCl}_{3}, \mathrm{rt}\right) \delta 8.65(\mathrm{~d}, J=4.5 \mathrm{~Hz}, 1 \mathrm{H}), 7.70$ (dt, $J=$ $7.8 \mathrm{~Hz}, J=1.8 \mathrm{~Hz}, 1 \mathrm{H}), 7.47(\mathrm{~d}, J=6.9 \mathrm{~Hz}, 3 \mathrm{H}), 7.43-7.28(\mathrm{~m}, 3 \mathrm{H}), 7.27-7.19(\mathrm{~m}, 1 \mathrm{H}), 4.17$ (bs, $2 \mathrm{H}), 1.14(\mathrm{~s}, 9 \mathrm{H}) ;{ }^{1} \mathrm{H}$ NMR $\left(500 \mathrm{MHz}, \mathrm{CDCl}_{3},-20{ }^{\circ} \mathrm{C}\right) \delta 8.74-8.61(\mathrm{~m}, 1 \mathrm{H}), 7.79-7.69(\mathrm{~m}, 1 \mathrm{H})$, 7.62-7.32 (m, 6H), 7.32-7.24 (m, $1 \mathrm{H}), 4.44$ and $4.29(\mathrm{~d}, J=3.5 \mathrm{~Hz}, 1 \mathrm{H}), 4.10$ and $3.83(\mathrm{~d}, J=$ $3.5 \mathrm{~Hz}, 1 \mathrm{H}), 1.16$ and $1.14(\mathrm{~s}, 9 \mathrm{H}) ;{ }^{13} \mathrm{C}$ NMR $\left(125 \mathrm{MHz}, \mathrm{CDCl}_{3},-20{ }^{\circ} \mathrm{C}\right) \delta 155.98,152.98$, $150.02,149.60,136.83,136.77,136.62,131.91,129.82,128.78,128.72,128.41,128.02,126.80$, 123.81, 123.35, 122.95, 122.79, 57.34, 57.18, 51.13, 48.93, 36.54, 36.36, 22.63, 22.63; Anal. Calcd. for $\mathrm{C}_{17} \mathrm{H}_{20} \mathrm{~N}_{2} \mathrm{OS}$ : C, 67.97; H, 6.71; N, 9.32. Found: C, 67.81; H, 6.66; N, 9.21. 
cis-1-(tert-Butanesulfinyl)-2-(2-pyridyl)-3-phenylaziridine (cis-3i). (absolute configuration not determined) White crystals; m.p. $105-7^{\circ} \mathrm{C} ; \mathrm{R}_{f} 0.16$ (hexanes/ethyl acetate, $\left.70: 30\right) ;[\alpha]_{D}^{23}=$ $+76.0^{\circ}\left(\mathrm{c} 0.5, \mathrm{CHCl}_{3}\right)$; IR (film): 2977, 1590, 1473, 1434, 1071, 890, $761 \mathrm{~cm}^{-1}$; MS m/z (\%): 195 (23), 182 (100), 167 (20), 92 (68); ${ }^{1} \mathrm{H}$ NMR (300 MHz, $\left.\mathrm{CDCl}_{3}\right) \delta 8.44$ (d, J=4.5 Hz, 1H), 7.39 $(\mathrm{t}, J=7.8 \mathrm{~Hz}, 1 \mathrm{H}), 7.29-7.07(\mathrm{~m}, 5 \mathrm{H}), 7.06-6.93(\mathrm{~m}, 2 \mathrm{H}), 4.30(\mathrm{~d}, J=7.2 \mathrm{~Hz}, 1 \mathrm{H}), 3.78(\mathrm{~d}, J=$ $7.2 \mathrm{~Hz}, 1 \mathrm{H}), 1.30(\mathrm{~s}, 9 \mathrm{H}) ;{ }^{13} \mathrm{C} \mathrm{NMR}\left(75 \mathrm{MHz}, \mathrm{CDCl}_{3}\right) \delta 154.11,149.25,135.78,133.46,128.09$, 127.99, 127.53, 122.35, 122.07, 57.22, 42.14, 40.29, 22.83; Anal. Calcd. for $\mathrm{C}_{17} \mathrm{H}_{20} \mathrm{~N}_{2} \mathrm{OS}$ : C, 67.97; H, 6.71; N, 9.32. Found: C, 66.57; H, 6.64; N, 9.12.

\section{Acknowledgements}

We thank the Robert A. Welch Foundation for financial support of this research project (Grant No. D-1635).

\section{Supplementary Material}

${ }^{1} \mathrm{H}$ NMR and ${ }^{13} \mathrm{C}$ NMR spectra for all new compounds.

\section{References}

1. Taken in part from the doctoral dissertation: Xue, Z. Ph.D. Thesis, Texas Tech University, 2009.

2. (a) Ismail, F. M. D.; Levitsky, D. O.; Dembitsky, V. M. Eur. J. Med. Chem. 2009, 44, 3373.

(b) Singh, G. S.; D’hooghe, M.; De Kimpe, N. Chem. Rev. 2007, 107, 2080. (c) Watson, I.

D. G.; Yu, L.; Yudin, A. K. Acc. Chem. Res. 2006, 39, 194. (d) Hu, X. E. Tetrahedron 2004, 60, 2701. (e) Sweeney, J. B. Chem. Soc. Rev. 2002, 31, 247. (f) Zwanenburg, B.; ten Holte, P. Top. Curr. Chem. 2001, 216, 93.

3. For reviews of aziridine synthesis, see: (a) Padwa, A.; Murphree, S. S. Arkivoc 2006, 3, 6. (b) Sweeney, J. B. In Aziridines and Epoxides in Organic Synthesis; Yudin, A. K., Ed.; Wiley-VCH: Weinheim, 2006; Chapter 4. (c) Mößner, C.; Bolm, C. In Transition Metals for Organic Synthesis; Beller, M.; Bolm, C., Eds.; Wiley-VCH: Weinheim, 2004; p. 389. (d) Müller, P.; Fruit, C. Chem. Rev. 2003, 103, 2905. (e) McCoull, W.; Davis, F. A. Synthesis 2000, 1347. (f) Jacobsen, E. N. In Comprehensive Asymmetric Catalysis; Jacobsen, E. N.; Pfaltz, A.; Yamamoto, H., Eds.; Springer: New York, 1999; Chapter 17. (g) Li, A.-H.; Dai, L.-X.; Aggarwal, V. K. Chem. Rev. 1997, 97, 2341. (h) Pearson, W. H.; Lian, B. W.; Bergmeier, S. C. In Comprehensive Heterocyclic Chemistry II, Vol. 1A; Padwa, A., Ed.; Pergamon: Oxford, 1996; p. 1. (i) Tanner, D. Angew. Chem., Int. Ed. Engl. 1994, 33, 599. 
4. Friestad, G. K.; Mathies, A. K. Tetrahedron 2007, 63, 2541.

5. (a) Forbes, D. C.; Bettigeri, S. V.; Amin, S. R.; Bean, C. J.; Law, A. M.; Stockman, R. A. Synth. Commun. 2009, 39, 2405. (b) Chigboh, K.; Morton, D.; Nadin, A.; Stockman, R. A. Tetrahedron Lett. 2008, 49, 4768. (c) Morton, D.; Pearson, D.; Field, R. A.; Stockman, R. A. Chem. Commun. 2006, 1833. (d) Fernández, I.; Valdivia, V.; Gori, B.; Alcudia, F.; Alvarez, E.; Khiar, N. Org. Lett. 2005, 7, 1307. (e) Morton, D.; Pearson, D.; Field, R. A.; Stockman, R. A. Org. Lett. 2004, 6, 2377. (f) Morton, D.; Pearson, D.; Field, R. A.; Stockman, R. A. Synlett 2003, 1985. (g) García Ruano, J. L.; Fernández, I.; del Prado Catalina, M.; Cruz, A. A. Tetrahedron: Asymmetry 1996, 7, 3407. (h) García Ruano, J. L.; Fernández, I.; Hamdouchi, C. Tetrahedron Lett. 1995, 36, 295. (i) Davis, F. A.; Zhou, P.; Liang, C.-H.; Reddy, R. E. Tetrahedron: Asymmetry 1995, 6, 1511.

6. For related non-asymmetric examples, see: (a) Kokotos, C. G.; McGarrigle, E. M.; Aggarwal, V. K. Synlett 2008, 2191. (b) Chigboh, K.; Nadin, A.; Stockman, R. A. Synlett 2007, 2879. (c) Arini, L. G.; Sinclair, A.; Szeto, P.; Stockman, R. A. Tetrahedron Lett. 2004, 45, 1589. (d) Yang, X.-F.; Zhang, M.-J.; Hou, X.-L.; Dai, L.-X. J. Org. Chem. 2002, 67, 8097. (e) Aggarwal, V. K.; Stenson, R. A.; Jones, R. V. H.; Fieldhouse, R.; Blacker, J. Tetrahedron Lett. 2001, 42, 1587. (f) Li, A.-H.; Zhou, Y.-G.; Dai, L.-X.; Hou, X.-L.; Xia, L.-J.; Lin, L. J. Org. Chem. 1998, 63, 4338. (g) Hou, X.-L.; Yang, X.-F.; Dai, L.-X.; Chen, X.-F. Chem. Commun. 1998, 747. (h) Zhou, Y.-G.; Li, A.-H.; Hou, X.-L.; Dai, L.-X. Tetrahedron Lett. 1997, 38, 7225. (i) Wang, D.-K.; Dai, L.-X.; Hou, X.-L. Chem. Commun. 1997, 1231. (j) Mosset, P.; Grée, R. Synth. Commun. 1985, 15, 749. (k) Tewari, R. S.; Awasthi, A. K.; Awasthi, A. Synthesis 1983, 330. (1) Corey, E. J.; Chaykovsky, M. J. Am. Chem. Soc. 1965, 87, 1353. (m) Corey, E. J.; Chaykovsky, M. J. Am. Chem. Soc. 1962, 84, 3782.

7. For related asymmetric examples, see: (a) Arroyo, Y.; Meana, Á.; Rodríguez, J. F.; SanzTejedor, M. A.; Alonso, I.; García Ruano, J. L. J. Org. Chem. 2009, 74, 4217. (b) Janardanan, D.; Sunoj, R. B. J. Org. Chem. 2008, 73, 8163. (c) Iska, V. B. R.; Gais, H.-J.; Tiwari, S. K.; Babu, G. S.; Adrien, A. Tetrahedron Lett. 2007, 48, 7102. (d) Midura, W. H. Tetrahedron Lett. 2007, 48, 3907. (e) Robiette, R. J. Org. Chem. 2006, 71, 2726. (f) Solladié-Cavallo, A.; Roje, M.; Welter, R.; Šunjić, V. J. Org. Chem. 2004, 69, 1409. (g) Saito, T.; Sakairi, M.; Akiba, D. Tetrahedron Lett. 2001, 42, 5451. (h) Baird, C. P.; Taylor, P. C. J. Chem. Soc., Perkin Trans. 1 1998, 3399. (i) Li, A.-H.; Zhou, Y.-G.; Dai, L.-X.; Hou, X.-L.; Xia, L.-J.; Lin, L. Angew. Chem. Int. Ed. Engl. 1997, 36, 1317.

8. (a) Aggarwal, V. K.; Ferrara, M.; O’Brien, C. J.; Thompson, A.; Jones, R. V. H.; Fieldhouse, R. J. Chem. Soc., Perkin Trans. 1 2001, 1635. (b) Aggarwal, V. K.; Alonso, E.; Fang, G.; Ferrara, M.; Hynd, G.; Porcelloni, M. Angew. Chem. Int. Ed. 2001, 40, 1433. (c) Aggarwal, V. K.; Thompson, A.; Jones, R. V. H.; Standen, M. C. H. J. Org. Chem. 1996, 61, 8368.

9. For recent representative examples, see: (a) Zhang, Y.; Lu, Z.; Wulff, W. D. Synlett 2009, 2715. (b) Ranocchiari, M.; Mezzetti, A. Organometallics 2009, 28, 3611. (c) Zhang, X.; Yan, M.; Huang, D. Org. Biomol. Chem. 2009, 7, 187. (d) Bew, S. P.; Carrington, R.; Hughes, D. L.; Liddle, J.; Pesce, P. Adv. Synth. Catal. 2009, 351, 2579. (e) Zeng, X.; Zeng, 
X.; Xu, Z.; Lu, M.; Zhong, G. Org. Lett. 2009, 11, 3036. (f) Akiyama, T.; Suzuki, T.; Mori, K. Org. Lett. 2009, 11, 2445. (g) Hashimoto, T.; Uchiyama, N.; Maruoka, K. J. Am. Chem. Soc. 2008, 130, 14380. (h) Wipf, P.; Lyon, M. A. Arkivoc 2007, 12, 91. (i) Pellicciari, R.; Amori, L.; Kuznetsova, N.; Zlotsky, S.; Gioiello, A. Tetrahedron Lett. 2007, 48, 4911. (j) Zhu, S.; Liao, Y.; Zhu, S. Synlett 2005, 1429. (k) Lee, S.-H.; Song, I.-W. Bull. Korean Chem. Soc. 2005, 26, 223. (1) Vanderhoydonck, B.; Stevens, C. V. Synthesis 2004, 722. (m) Li, Y.; Chan, P. W. H.; Zhu, N.-Y.; Che, C.-M.; Kwong, H.-L. Organometallics 2004, 23, 54. (n) Redlich, M.; Hossain, M. M. Tetrahedron Lett. 2004, 45, 8987. (o) Williams, A. L.; Johnston, J. N. J. Am. Chem. Soc. 2004, 126, 1612. (p) Krumper, J. R.; Gerisch, M.; Suh, J. M.; Bergman, R. G.; Tilley, T. D. J. Org. Chem. 2003, 68, 9705. (q) Yadav, J. S.; Reddy, B. V. S.; Rao, M. S.; Reddy, P. N. Tetrahedron Lett. 2003, 44, 5275. (r) Morales, D.; Pérez, J.; Riera, L.; Riera, V.; Corzo-Suárez, R.; García-Granda, S.; Miguel, D. Organometallics 2002, 21, 1540. (s) Mayer, M. F.; Wang, Q.; Hossain, M. M. J. Organomet. Chem. 2001, 630, 78. (t) Doyle, M. P.; Hu, W.; Timmons, D. J. Org. Lett. 2001, 3, 933. (u) Crousse, B.; Narizuka, S.; Bonnet-Delpon, D.; Bégué, J.-P. Synlett 2001, 679. (v) Sengupta, S.; Mondal, S. Tetrahedron Lett. 2000, 41, 6245. (w) Kubo, T.; Sakaguchi, S.; Ishii, Y. Chem. Commun. 2000, 625. (x) Xie, W.; Fang, J.; Li, J.; Wang, P. G. Tetrahedron 1999, 55, 12929. (y) Juhl, K.; Hazell, R. G.; Jørgensen, K. A. J. Chem. Soc., Perkin Trans. 1 1999, 2293. (z) Nagayama, S.; Kobayashi, S. Chem. Lett. 1998, 685.

10. (a) Ferreira, F.; Botuha, C.; Chemla, F.; Pérez-Luna, A. Chem. Soc. Rev. 2009, 38, 1162. (b) Morton, D.; Stockman, R. A. Tetrahedron 2006, 62, 8869. (c) Davis, F. A.; Yang, B.; Deng, J.; Zhang, J. Arkivoc 2006, 7, 120. (d) Zhou, P.; Chen, B.-C.; Davis, F. A. Tetrahedron 2004, 60, 8003. (e) Ellman, J. A. Pure Appl. Chem. 2003, 75, 39. (f) Ellman, J. A.; Owens, T. D.; Tang, T. P. Acc. Chem. Res. 2002, 35, 984.

11. Davis, F. A.; Liu, H.; Zhou, P.; Fang, T.; Reddy, G. V.; Zhang, Y. J. Org. Chem. 1999, 64, 7559.

12. (a) Denolf, B.; Mangelinckx, S.; Törnroos, K. W.; De Kimpe, N. Org. Lett. 2006, 8, 3129.

(b) Denolf, B.; Leemans, E.; De Kimpe, N. J. Org. Chem. 2007, 72, 3211.

13. Davis, F. A.; Wu, Y.; Yan, H.; McCoull, W.; Prasad, K. R. J. Org. Chem. 2003, 68, 2410.

14. (a) Chemla, F.; Ferreira, F. Synlett 2004, 983. (b) Chemla, F.; Ferreira, F. J. Org. Chem. 2004, 69, 8244. (c) Ferreira, F.; Audouin, M.; Chemla, F. Chem. Eur. J. 2005, 11, 5269.

15. Zheng, J.-C.; Liao, W.-W.; Sun, X.-X.; Sun, X.-L.; Tang, Y.; Dai, L.-X.; Deng, J.-G. Org. Lett. 2005, 7, 5789.

16. (a) Xue, Z.; Mazumdar, A.; Hope-Weeks, L. J.; Mayer, M. F. Tetrahedron Lett. 2008, 49, 4601. (b) Mazumdar, A.; Xue, Z.; Mayer, M. F. Synlett 2007, 2025.

17. Aggarwal, V. K.; Charmant, J. P. H.; Ciampi, C.; Hornby, J. M.; O’Brien, C. J.; Hynd, G.; Parsons, R. J. Chem. Soc., Perkin Trans. $12001,3159$.

18. Single crystals of $\left(R_{S}, 2 R, 3 R\right)-1$-(tert-butanesulfinyl)-2-(4-nitrophenyl)-3-phenylaziridine $\left(\left(R_{S}, 2 R, 3 R\right)-3 \mathbf{a}\right)$ and $\left(R_{S}, 2 S, 3 S\right)$-1-(tert-butanesulfinyl)-2-(4-nitrophenyl)-3-phenylaziridine $\left(\left(R_{S}, 2 S, 3 S\right)-3 \mathbf{a}\right)$ that were suitable for $\mathrm{x}$-ray crystallographic analysis were grown from a 
$\mathrm{CH}_{2} \mathrm{Cl}_{2} / \mathrm{MeOH}$ (1:1) solution. Crystallographic data (excluding structure factors) for the structures of $\left(R_{S}, 2 R, 3 R\right)-\mathbf{3 a}$ and $\left(R_{S}, 2 S, 3 S\right)$-3a in this paper have been deposited with the Cambridge Crystallographic Data Centre as supplementary publication number CCDC 759961 and 759962, respectively. Copies of the data can be obtained, free of charge, on application to CCDC, 12 Union Road, Cambridge CB2 1EZ, UK, (fax: +44-(0)1223-336033 or e-mail: deposit@ccdc.cam.ac.uk).

19. (a) Brois, S. J. J. Am. Chem. Soc. 1963, 85, 1882. (b) Davies, M. W.; Shipman, M.; Tucker, J. H. R.; Walsh, T. R. J. Am. Chem. Soc. 2006, 128, 14260. (c) Davies, M. W.; Clarke, A. J.; Clarkson, G. J.; Shipman, M.; Tucker, J. H. R. Chem. Commun. 2007, 5078.

20. Creary, X. Org. Synth. 1986, 64, 207.

21. Liu, G.; Cogan, D. A.; Ellman, J. A. J. Am. Chem. Soc. 1997, 119, 9913.

22. Liu, G.; Cogan, D. A.; Owens, T. D.; Tang, T. P.; Ellman, J. A. J. Org. Chem. 1999, 64, 1278.

23. Huang, Z.; Zhang, M.; Wang, Y.; Qin, Y. Synlett 2005, 1334. 